\title{
Small-scale Coconut Farmers in Indragiri Hilir District as a Model of Youth Entrepreneurship in the Plantation Sector
}

\author{
Mulono Apriyanto ${ }^{1}{ }^{*}$ Prety Diawati ${ }^{2}$, Latarus Fangohoi ${ }^{3}$, Elfarisna $^{4}$, Faidah Azuz $^{5}$, \\ Eko Sutrisno $^{6}$
}

${ }^{1}$ Dept. Agriculture, Islamic University of Indragiri, Indonesia

${ }^{2}$ Dept. Business Management, Politeknik Pos Indonesia, Bandung, Indonesia

${ }^{3}$ Dept. Agriculture extension, Manokwari Agricultural Development Polytechnic, Indonesia

${ }^{4}$ Dept. Agriculture, University of Muhammadiyah Jakarta, Indonesia

${ }^{5}$ Dept. Agribusiness, Bosowa University, Makasar, Indonesia

${ }^{6}$ Agricultural Technology, Majapahit Islamic University, Indonesia

${ }^{*}$ Corresponding author.Email: mulonoapriyanto71@gmail.com

\begin{abstract}
Young people's entrepreneurship in agriculture is very popular in Indragiri Hilir. The low level of youth involvement in the marketing chain of coconut plantation products needs to receive little attention-a comparative analysis of youth and the elderly in coconut production and marketing in Indragiri Hilir.
\end{abstract}

Keywords: High-value markets, market participation, plantation, youth.

\section{INTRODUCTION}

Coconut (Cocos nucifera L.) is a tropical mainstay plant that grows in more than 80 countries and produces 61 million tons per year. Coconut was available in different forms: coconut milk, coconut juice, coconut flour, coconut oil, and dried coconut. Dried coconut with a moisture level of less than $3 \%$ basic dry weight can be used to remodel ice cream, cakes, doughnuts, and flavour chocolate bars, pastries, and biscuits. [1]-[3]. Youth involvement in the value chain of farms has received minimal attention. A study conducted a comparative evaluation of youth and the elderly in the Indragiri Hilir district's coconut production and marketing. The research found differences in background characteristics between youth and older adults [4].

Furthermore, youth participation in agriculture is essential for replacing agriculture's elderly population, which averaged nearly 50 years of age, reducing imports of staple foods such as rice and frozen foods, improving plant imagery, reducing rural-urban migration and social problems, and reducing rural youth unemployment. Youth involvement in agriculture can contribute to achieving the Sustainable Development Goals (SDGs) 1 and 8 , which also target solving poverty and stimulating economic development, and ten aim to reduce inequality [5].

\section{MATERIAL AND METHODS OF USE}

\subsection{Study area and data collection}

Indragiri Hilir regency is a coconut producer with 310 million tons/year [6]. Coconut plantations, corn farming, and rice cultivation are the district's principal agricultural economic activity. Some sub-districts are coconut producers such as Keritang, Reteh, Tanah Merah, Kuala Indragiri, Enok, Batang Tuaka, Gaung, Mandah, Kateman and Plangiran as the main agricultural activities. This district recorded the highest economic activity. Coconut production is quite great in the downstream Indragiri region due to the climatic circumstances, and it is the primary crop with a significant economic value. The enormous output of coconuts in Indragiri Hilir has resulted in numerous coconut-housing businesses, but marketing practices remain traditional. The high rate of coconut production in these areas provides an excellent opportunity to examine youth involvement in the coconut value chain in lower Indragiri. 
The study's participants were chosen using a threestage selection technique. Keritang, Enok and Batang Tuaka districts were chosen purposively because of the relatively high level of coconut production. Eight villages in the district were randomly selected (Sungai Raya, Sungai Junjangan, Sungai Rukam, Keritang, Kota Baru, Enok, Teluk Dalam). Two hundred twenty-four coconut farmers were randomly selected using systematic sampling methods.[6]. The primary data was collected using semi-structured questionnaires from these farmers.

\subsection{Methods of analysis}

The study used descriptive statistics to investigate differences in socioeconomic characteristics and access to institutional and support services between young and old mango farmers. A t-test was used to determine the significance of these differences for continuous variables, and a chi-square test was used for categorical variables.

\section{YOUTH AND THE ELDERLY IN INDRAGIRI HILIR COCONUT PRODUCTION AND MARKETING: A COMPARATIVE ANALYSIS}

According to the report, 40.61 percent of farmers in Indragiri Hilir are teenagers with an average age of roughly 31 years, while nearly 61.82 percent of coconut farmers reside in Indragiri Hilir. The average age of coconut farmers in Indragiri Hilir is roughly 52 years. The following table illustrates young and old coconut farmers regarding the economic status and access to institutional services and support regarding coconut production and selling.

Table 1. The table below compares young and old farmers regarding socioeconomic factors and access to institutional services and assistance for coconut production and selling.

\begin{tabular}{|c|c|c|c|}
\hline Variables & $\begin{array}{c}\text { Youth }(\mathrm{N}= \\
45) \\
\text { Mean } \\
\end{array}$ & $\begin{array}{c}\text { Elderly }(\mathrm{N}= \\
179) \\
\text { Mean }\end{array}$ & Difference \\
\hline Age (Years) & 40.61 & 61.82 & $-20.19 * *$ \\
\hline $\begin{array}{c}\text { Years of } \\
\text { schooling }\end{array}$ & 9.65 & 8.39 & $1.30 * * *$ \\
\hline Household size & 3.47 & 5.63 & $-2.16 * * *$ \\
\hline $\begin{array}{c}\text { Total } \\
\text { household } \\
\text { income }\end{array}$ & $2.318 .000,44$ & $3.2774 .000,78$ & $\begin{array}{c}- \\
4556.34 * * \\
*\end{array}$ \\
\hline Coconut sales & 6262.89 & 9477.10 & $3314.21 * *$ \\
\hline $\begin{array}{l}\text { Non-coconut } \\
\text { income }\end{array}$ & 1055.56 & 3409.64 & $-2454.09 *$ \\
\hline $\begin{array}{l}\text { coconut land } \\
\text { size }\end{array}$ & 4.96 & 6.27 & -1.31 \\
\hline
\end{tabular}

This conclusion is consistent with [7]-[9], who discovered that parents dominate agriculture in Indragiri Hilir. On the subject of education, the survey discovered that youth engaged in coconut farming were more educated, with an average school year lasting 2.67 years, compared to parents, who reported an average school year lasting 9.2 years. This indicates that after graduating high school, youth become active in coconut farming[8], [10], [11]. The difference in school years between youth and parents was statistically significant at a significant rate of $1 \%$. The average household size of the elderly working in coconut farming was 5.63, which was more than the average household size of youth, which was 3.47 . The conclusions are selfevident: as people age, they are more likely to have children. Between youth and the elderly, the difference in household size was statistically significant at a rate of $1 \%$. According to study's study of household income, elderly individuals engaged in coconut farming earned an average of Rp.3.2774.000.78 as much as adolescents engaged in coconut farming, who earned an average of Rp.2,318,000.44. When coconut farming is considered the primary source of income for coconut-producing households in the study area, the elderly's relatively high income can be attributed to their relatively high coconut sales during the subsequent harvest season, which averaged Rp. 2. 477.000/10 kg, compared to young farmers' lower coconut sales of $\mathrm{Rp}$. $2,300,000 / 100 \mathrm{~kg}$.

Additionally, elderly adults get a higher average non-coconut income of Rp. 3409.64, while youth earn a lower average of $\mathrm{Rp}$. 1055.56. This indicates that parents engage in more lucrative activities than young activities apart from coconut farming. Between the young and the elderly, differences in household income, coconut sales, and non-coconut income were statistically significant at $1 \%, 5 \%$, and $10 \%$, respectively. Although the difference is not statistically significant, older coconut farmers cultivate an average of 6.27 hectares, compared to younger coconut farmers, who cultivate approximately 4 hectares. That demonstrates that land access is not a significant barrier to young people engaging in coconut farming as discovered in food crops.

The logit model indicated that seven out of ten explanatory variables were statistically significant at the $1 \%, 5 \%$, and $10 \%$ levels. The chi-square statistic of 103.9008 indicates that the probability ratio statistics are highly significant ( $\mathrm{p} 0.000$ ), suggesting a high degree of explanatory power for such a model. As expected, a farmer's age significantly impacts their involvement in high-value marketplaces $(p=0.002)$. Being a young male significantly diminishes one's chances of participating in the high-value coconut market by up to $60 \%$. This is because youths lack the assets, increased networks, and experience required to expedite their commercialization in lucrative sectors [5].

The household size was found to have a statistically significant effect on involvement in high-value markets $(p=0.031)$. A one-person increase in a household size 
decreases a farmer's potential to engage in a strong valuation by $4 \%$. Having a larger household promotes food crop production while decreasing coconut plant cultivation [12], [13]. Another argument is that having a big household reduces agricultural investment, as a greater proportion of household income is diverted to support the needs of other households. As a result, they sell to lesser-value markets, such as local shopkeepers, resulting in fewer earnings. As expected, the size of the land affects one's ability to participate in the high-value market $(p=0.095)$. By increasing the area of coconut land by one acre, a farmer's likelihood of participating in a high-value market increases by $2 \%$. This is because purchasers in high-value markets, such as those for export, prefer greater agricultural sizes [14], [15]. Another reason is that a bigger agricultural area enables farmers to maintain the proper distance, reducing competition for nutrients among trees. This further enhances the fruits' quality, enabling growers to meet the high-value market's quality criteria.

Storage availability has a considerable effect on participation in high-value marketplaces $(\mathrm{p}=0.000)$. When coconut growers gain access to storage facilities, their likelihood of participating in high-value marketplaces increases by 49 percent. Some farmers in the study area keep coconuts by heaping them on the earth. This technique degrades the coconut's physical qualities [16]. These farmers, among others, who lack access to storage facilities are less likely to match the standards of high-value marketplaces, so excluding them from participation.

Rickshaw ownership has a beneficial effect on the market for high-value coconuts $(\mathrm{p}=0.048)$. When a farmer acquires a rickshaw, their chance of participating in a high-value market improves by up to 24 percent. Transportation tools minimize transaction costs; thus, farmers benefit from higher gross margins when they own transportation tools [15], [17]. Farmers can reach high-value markets such as processors and supermarkets via their vehicles. Access to this business is usually hampered by insufficient transportation.

\section{CONCLUSION}

The research found significant differences in socioeconomic characteristics and accessibility to institutional services and support in coconut production between youth and older people engaged in agriculture in lower Indragiri. The majority of factors in this model have a substantial impact on the level of engagement of young people in the market for high-value coconuts. Farmers' chances of participating in high-value coconut markets are diminished by their family size and age, whereas participation in high-value coconut markets is facilitated by large coconut farms, access to storage facilities, ownership of means of transportation, and age interaction and access to credit, in addition to age and certification. These differences are exacerbated by the school year, household size, total household income, coconut sales, non-coconut sales, the amount of coconut land, certification, participation in farmer-based organizations, access to coconut market information, and extension services. This demonstrates that certification and credit enable young people to access lucrative marketplaces, increasing their income and, thus, their livelihoods. Thus, coconut manufacturing and selling provide excellent prospects for young people to earn a living through certification and credit.

\section{AUTHORS' CONTRIBUTIONS}

Mulono Apriyanto's contribution as the inventor of the research idea. Prety Diawati and Faidah Azuz made substantial contributions to marketing economics. Fangohoi and Elfarisna's origins affected the type of farmer they became. Eko Sutrisno provided articles and writing to this publication. Mulono Apriyanto's contribution as the founder of the research idea. Prety Diawati and Faidah Azuz contributed significantly to the study of marketing economics. Fangohoi and Elfarisna's origins affected the type of farmer they became. Eko Sutrisno contributed articles and writing to this collection.

\section{ACKNOWLEDGMENTS}

This work obtained funding from the Regional Government of Indragiri Hilir Regency through the plantation office to sponsor research on the welfare of coconut farmers. Special thanks to the sample farmers and respondents who participated in the study.

\section{REFERENCES}

[1] R. Akrong, S. G. Mbogoh, and P. Irungu, "Youth agripreneurship in the horticultural value-chain: The case of small-scale mango farmers in Southern Ghana," African Dev. Rev., vol. 32, 2020, doi: 10.1111/1467-8268.12483.

[2] S. P. I. Wage and S. Molek, "Akuntansi Sosial dan Pendampingan Pembuatan Produk," Ekon. Lingkung., 2021, [Online]. Available: https://books.google.com/books?hl=en\&lr $=\& \mathrm{id}=\mathrm{hZ}$ Y2EAAAQBAJ\&oi=fnd\&pg=PA175\&dq=penentu an + indeks $+\mathrm{k}+$ terhadap + harga + kelapa + sawit\&ots $=$ ACuARuXpLT\&sig=7Z19glVhCzejRXhcfhmLT3I TDLs.

[3] M. Apriyanto, "Pelatihan Dan Pendampingan Pengolahan Komoditas Kelapa," JPPM (Jurnal Pengabdi. dan Pemberdaya. Masyarakat), vol. 3, no. 2, pp. 179-183, 2019.

[4] M. Masganti, K. Anwar, and M. A. Susanti, "Potensi dan Pemanfaatan Lahan Gambut Dangkal untuk Pertanian," J. Sumberd. Lahan, vol. 11, no. 1, p. $\quad 43=52, \quad 2020, \quad$ doi: 10.21082/jsdl.v11n1.2017.43-52. 
[5] M. Apriyanto, B. F. S. Marlina, A. Rifa, and ..., "A SWOT Analysis to Improve The Marketing of Young Coconut Chips," Ann. Rom. .., 2021, [Online]. Available: http://annalsofrscb.ro/index.php/journal/article/vie w/4337.

[6] Hartono, Kabupaten Indragiri Hilir Dalam Angka 2020. 2020.

[7] T. Thanaraj, N. D. A. Dharmasena, and U. Samarajeewa, "Comparison of drying behaviour, quality and yield of copra processed in either a solar hybrid dryer on in an improved copra kiln," Int. J. Food Sci. Technol., vol. 42, no. 2, pp. 125132, 2007, doi: 10.1111/j.1365-2621.2006.01087.x.

[8] R. K. Megalingam, K. M. Sakthiprasad, M. M. Sreekanth, and G. V. Vivek, "A Survey on Robotic Coconut Tree Climbers - Existing Methods and Techniques," IOP Conf. Ser. Mater. Sci. Eng., vol. 225, no. 1, 2017, doi: 10.1088/1757$899 X / 225 / 1 / 012201$.

[9] M. Apriyanto, "Recovery Protein BY PRODUCT Virgin Coconut Oil," J. Teknol. Pertan., vol. 9, no. 1, pp. 14-18, 2020.

[10] G. Prato, C. Barrier, P. Francour, V. Cappanera, and ..., "Assessing interacting impacts of artisanal and recreational fisheries in a small Marine Protected Area (Portofino, NW Mediterranean Sea),"..., 2016, doi: 10.1002/ecs2.1601.

[11] N. P. Kurnianingsih, M. Maherawati, and ..., "Traditional Coconut Oil Purification Using Activated Charcoal Coconut Shell Adsorbents,"... J. Ilmu-Ilmu .., 2020, [Online]. Available: http://journal.univetbantara.ac.id/index.php/agrisai ntifika/article/view/848.

[12] N. P. T. Nhan et al., "Application of response surface methodology to optimise the process of saponification reaction from coconut oil in Ben Tre - Vietnam," Solid State Phenom., vol. 279 SSP, pp. 235-239, 2018, doi: 10.4028/www.scientific.net/SSP.279.235.

[13] C. Fidelis and B. K. Rajashekhar Rao, "Enriched cocoa pod composts and their fertilising effects on hybrid cocoa seedlings," Int. J. Recycl. Org. Waste Agric., vol. 6, no. 2, pp. 99-106, 2017, doi: 10.1007/s40093-017-0156-8.

[14] K. Y. Kamelé, A. K. Martial-Didie, N. Daouda, K. A. Carole, and ..., "Improvement of the quality of the cocoa during postharvest process in Côte d'Ivoire," J. Glob .... mutagens.co.in, 2019, [Online].
https://www.mutagens.co.in/jgb/vol.08/09/Journal of Global Biosciences 080901.pdf.

[15] J. A. Y. SINGH and K. SAHA, "Ecommerce Retail: Challenges and Opportunities for CPG Related Distribution Packaging," 21st IAPRI World Conf. ..., 2018, [Online]. Available: https://www.dpiproceedings.com/index.php/iapri2018/article/view/ 24387.

[16] X. B. Jofra and A. P. Gómez, "La logística como fuente de valor añadido al eCommerce," Revista de Economía, empresa y sociedad. comein.uoc.edu, 2018, [Online]. Available: http://comein.uoc.edu/divulgacio/oikonomics/_recu rsos/documents/09/3_Budet-

Perez1_Oikonomics_9_A4_cast.pdf.

[17] L. Xiao and Y. Zhang, "An analysis on the policy evolution of cross-border e-commerce industry in China from the perspective of sustainability," Electron. Commer. Res., 2020, doi: 10.1007/s10660-020-09427-y.337-351. DOI: https://doi.org/10.1007/3-540-11494-7_22 